Reprod. Nutr. Dévelop., 1988, 28 (4 B), 1129-1144

\title{
Development of the fetal pituitary-adrenal axis in the sheep
}

\author{
Véronique BRIEU, Anne-Marie CATHIARD $\left({ }^{*}\right)$, Halima DARBEIDA, Elisabeth \\ NAAMAN, J. M. SAEZ ( $\left.{ }^{*}\right)$, Ph. DURAND ( $\left.{ }^{1}\right)$ \\ Station de Physiologie de la Reproduction, I.N.R.A. \\ Nouzilly, 37380 Monnaie, France. \\ (*) INSERM, Hôpital Debrousse, 69322 Lyon Cedex 05, France.
}

Summary. In the ovine fetus, plasma levels of corticosteroids are very low between 60 and 130 days of gestation, then increase dramatically before birth. ACTH appears to be an important regulating hormone for the fetal adrenal cortex, the sensitivity of which to this hormone increases during late gestation. However, the relationship between immunoreactive ACTH and corticosteroids in the fetus is unclear. We review herein recent work performed in our laboratory on the regulation of ACTH secretion by ovine fetal pituitary cells and on the biochemical modifications responsible for the enhancement of the steroidogenic response to ACTH of fetal adrenal cells. It is suggested that qualitative together with quantitative changes in the pituitary drive to the fetal adrenal has to be taken in account to explain the rise of corticosteroids in prepartum animals. Also extra pituitary hormones may be operating during intrauterine life to regulate fetal adrenal function.

\section{Introduction.}

Numerous studies have demonstrated that in the ovine fetus, plasma levels of corticosteroids are very low between 60 and 130 days of gestation, then increase dramatically during the two weeks preceding parturition (Alexander et al., 1968 ; Bassett and Thorburn, 1969 ; Magyar et al., 1980 ; Wintour et al.. 1975). This increase results from an enhanced activity of the fetal adrenal cortex (Nathanielsz et al., 1972; Wintouret al., 1975) and induces both fetal maturation (review by Liggins, 1976) and parturition (reviews by Nathanielsz, 1978; Thorburn and Challis, 1979). Many experiments have pointed to ACTH as an important regulating hormone for the fetal adrenal cortex (review by Durand, 1987). However, data available from most laboratories suggest that the rise in fetal cortisol which precedes parturition occurs before any appreciable enhancement of fetal plasma immunoreactive ACTH level (Challis et al., 1977 ; Jones et al.,

(1) To whom correspondence should be addressed. 
1977 ; Rees et al., 1975 ; Wintour et al., 1980). On the other hand it is well established that from about 120 days of gestation, the responsiveness of fetal adrenal cells to ACTH increases to become maximal at the time of birth (review Durand et al., 1985c) ; but many gaps remain in our understanding of this process. In this paper, we review works performed, during the last 3 years, in our laboratory on the regulation of ACTH secretion by ovine fetal pituitary cells and on the biochemical modifications responsible for the enhancement of the steroidogenic response of fetal adrenal cells to ACTH. Finally we present recent data suggesting the occurrence of an additional extra pituitary regulation of fetal adrenocortical function.

\section{Regulation of ACTH secretion by the ovine pituitary gland.}

\section{1) Hormonal factors with ACTH-releasing activity in fetuses and lambs} (Durand et al., 1986).

In adult animals (mainly in the rat species) arginine vasopressin (AVP), oxytocin, catecholamines, angiotensin II (AII), and corticotropin-releasing factor (CRF) have been found to stimulate ACTH secretion (reviews by Yates and Maran, 1974 ; Yasuda et al., 1982). In the ovine fetus, the regulation of synthesis and secretion of ACTH by the pituitary remains poorly understood. Our first goal was to determine the identity of corticotropin-releasing hormones and their relative importance during fetal development.

Pituitary cells were isolated by collagenase treatment of whole glands from ovine fetuses between 63 and 144 days of gestation (parturition usually occurs at $145 \pm 1$ days postpartum), and from 1 - to 4 -month old lambs. Cells were then cultured in a mixture $(1: 1)$ of Ham's $F_{12}$ medium and Iscove's modified Dulbecco's medium. The second day after isolation, the cells were incubated in the absence or presence of ovine CRF (OCRF $\left.{ }_{1-41}\right)$, AVP, epinephrine or All, and their productions of both $\mathrm{CAMP}$ and $\mathrm{ACTH}$ were assessed by radioimmunoassays. Since nothing is known of the relative proportion of corticotrophs in the pituitary at different stages of development, the results have been expressed per $10^{5}$ corticotrophs after determination of the proportion of corticotrophs in each culture by an immunocytochemical method. Basal ACTH release did not vary greatly during the period studied. However, the maximal net ACTH response (stimulated-baseline) to oCRF ${ }_{1-41}$ decreased from $7.89 \pm 1.19 \mathrm{ng}$ at 63 days of gestation to $3.49 \pm 0.88 \mathrm{ng}$ at 115 days, then remained fairly constant in prepartum animals and in lambs (fig. 1). Likewise, the cAMP output induced by oCRF $_{1-41}$ decreased progressively between 63 and 133 days of gestation. The $\mathrm{ACTH}$ response to AVP (fig. 1 ) was higher than that to oCRF $\mathrm{F}_{1-41}$ at 115 days, decreased dramatically in late gestation and remained low in lambs. The ACTH response to epinephrine was always very low. The synergistic effect of AVP and epinephrine on both CAMP and ACTH productions stimulated by oCRF 1.41 decreased at the end of gestation. All, either alone or in combination with $\mathrm{OCRF}_{1-41}$, was unable to stimulate the release of $\mathrm{ACTH}$ by pituitary cells from either 126-day old ovine fetuses or sheep (table 1). Taken together, these results 


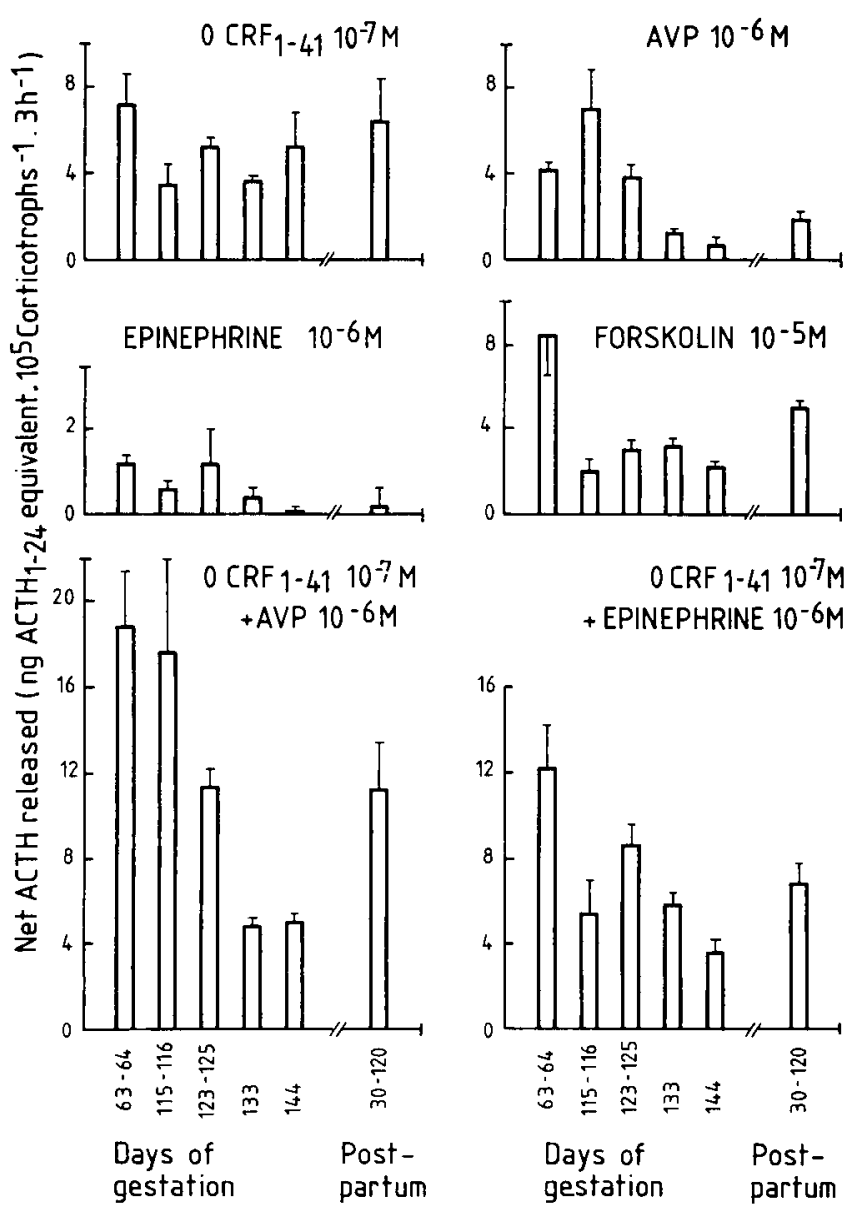

FIG. 1. - Effect of oCRF1-41 $\left(10^{-7} \mathrm{M}\right)$, AVP $\left(10^{-6} \mathrm{M}\right)$, and epinephrine $\left(10^{-6} \mathrm{M}\right)$ separately or in combination, and of forskolin $\left(10^{-6} \mathrm{M}\right)$ on the net release of ACTH (stimulated-baseline) by short term cultured pituitary cells from ovine fetuses and lambs. Results are the mean \pm SEM and are expressed by $10^{5}$ corticotrophs. From Durand et al., 1986.

indicate that $\mathrm{OCRF}_{1-41}$ and AVP are likely important factors regulating $\mathrm{ACTH}$ secretion by ovine pituitary cells. Moreover, they suggest that AVP might be a more important $A C T H$-releasing hormone than $\mathrm{OCRF}_{1-41}$ during fetal life. Somewhat paradoxically, its appears that the responsiveness of fetal corticotrophs to oCRF 1-41 $_{1}$ or to AVP, either alone or in combination, is lowest just before parturition, i.e. when ACTH concentration in the fetal circulation begins to rise (Hennessy et al., 1982). This result could be explained by the high plasma levels of cortisol observed at that time ; it might also convey a partial desensitization of pituitary cells resulting from an enhancement of the release of oCRF ${ }_{1-41}$ and/or 
TABLE 1

Immunoreactive ACTH released by short-term cultured pituitary cells from ovine fetuses and adult sheep

$\left(\mathrm{ng} / 3 \mathrm{~h} / 5 \times 10^{5}\right.$ cells)

\begin{tabular}{lll}
\hline & $\begin{array}{c}\text { Fetuses } \\
(126 \text { day old })\end{array}$ & Adult sheep \\
\hline Baseline & $1.33 \pm 0.04$ & $0.86 \pm 0.08$ \\
CRF $10^{-8} \mathrm{M}$ & $4.96 \pm 0.18^{*}$ & $2.89 \pm 0.21^{*}$ \\
Angiotensin $1110^{-7} \mathrm{M}$ & $1.20 \pm 0.04$ & $0.86 \pm 0.09$ \\
CRF + Angiotensin II & $4.75 \pm 0.07^{*}$ & $1.98 \pm 0.11^{*}$ \\
\hline
\end{tabular}

${ }^{*} \mathrm{P}<0.05$ vs baseline

AVP by the fetal hypothalamus in late gestation. This latter hypothesis is supported by the fact that hypothalamic contents and concentrations of AVP decrease dramatically before birth (unpublished results).

2) Bioactivity of the ACTH-like material released by pituitary cells from ovine fetuses and lambs (Brieu and Durand, 1987).

Different molecular weight forms of ACTH which cross-react in both $\mathrm{N}$-terminal and $\mathrm{C}$-terminal ACTH assays, but which possess different biological activity, have been found both in whole ovine fetal pituitary extracts and in fetal blood (Silman et al., 1979 ; Jones and Roebuck, 1980). Hence we compared the biological (B) and immunological (I) ACTH-like activities of the ACTH-like molecules released by cultured pituitary cells from ovine fetuses and lambs. The bioassay was based on the production of corticosteroids by cultured adult sheep adrenal cells.

These data showed marked discrepancies between I- and B-ACTH-like activity at some stages of development. Indeed, the $B / I$ ratio increased progressively from $0.29 \pm 0.04$ at 63 days of intrauterine life up to $0.70 \pm 0.04$ at 144 days. Conversely, for post-partum animals, the $B / I$ ratios were not different from 1, except in the case of stimulation by AVP alone when they were significantly higher than 1. Hence it appears that during development of the sheep, I-ACTH levels are probably not representative of the "corticotropic activity » released by the pituitary. Nevertheless, since plasma levels of I-ACTH in the ovine fetus remain stable (Challis et al., 1977 ; Rees et al., 1975 ; Jones et al., 1977 ; Wintour et al., 1980), or even increase slightly (Hennessy et al., 1982 ; Norman et al., 1985) in late gestation, our results suggest strongly that the prepartum rise in cortisol, together with fasciculata cell maturation (review by Durand et al., 1985b; and see below), does indeed result from an enhanced tropic drive to the fetal adrenal. The endocrinological causes of the increase in the $B / 1$ ratio remain to be fully elucidated. However our results suggest that AVP (and cortisol, see below) might be involved in this control. A 4-day treatment of the 
pituitary cells with $10^{-9} \mathrm{M}$ AVP resulted in a decrease in $\mathrm{B}$ - and I-ACTH-like activities released by AVP. However, the $B / I$ ratio was enhanced roughly 1.5 -fold as compared to control cells. That such a phenomenon could operate in vivo is suggested by very recent results showing that both hypothalamic contents and concentrations of AVP increase regularly between 63 and 138 days of gestation, then decrease abruptly in 143-day old ovine fetuses, to reincrease in newborn lambs (unpublished).

3) Mechanisms of feedback between corticosteroids and ACTH in the fetus (Durand et al., 1986 ; Brieu and Durand, 1987).

In adult animals, it is well established that ACTH secretion is negatively regulated by corticosteroid feedback which occurs at two and probably more sites (review by Keller-Wood and Dallman, 1984). However, in the ovine fetus, plasma levels of both cortisol and ACTH are elevated in the very last days of gestation, and physiological participation of corticosteroid feedback is still much debated.

We have observed recently that either cortisol or corticosterone $\left(10^{-9} \mathrm{M}\right.$ to $10^{-7} \mathrm{M}$ ) is able to decrease oCRF ${ }_{1-41^{-}}$induced $\mathrm{ACTH}$ release by cultured pituitary corticotrophs from ovine fetuses between 63 and 144 days (fig. 2). However, it has to be underlined that at the very end of gestation (between 133 and 144 days) both cortisol and corticosterone at $10^{-9} \mathrm{M}$ are no longer able to inhibit but, conversely, increase the ACTH response of fetal corticotrophs to AVP. Morever the $\mathrm{B} / \mathrm{I}$ ratio of $\mathrm{ACTH}$-like material secreted under AVP stimulation by pituitary cells from 120-day old ovine fetuses, cultured for 4 days in the presence of cortisol, is higher than that of control cells. These latter results are in favor of the occurrence of a positive effect of cortisol on the "corticotropic activity" released by the pituitary of fetuses just before parturition as already suggested (Jones et al., 1978).

\section{Biochemical steps involved in the enhancement of the responsive- ness of fetal adrenal cells in late gestation to ACTH.}

There are many ways through which an endocrine gland may develop its responsiveness to a specific hormonal stimulus. Such a phenomenon may convey an increased number of responsive cells and/or an enhanced sensitivity to the hormone of some of the constitutive cells. The important growth of the ovine fetal adrenal cortex in late gestation involves both cellular hyperplasia and hypertrophy (Durand et al., 1978; Webb, 1980). Moreover, some of the biochemical modifications responsible for the enhancement of the steroidogenic response to ACTH of the ovine fetal adrenal before birth are currently known. This process appears to result from (1) an increased responsiveness to ACTH of the adenylate cyclase (Durand et al., 1981b), which is due to an increase in the number of ACTH receptors (Durand, 1979) and to a development of the stimulatory guanine nucleotide binding component ( $N$ s or $\mathrm{Gs}$ ) (Durand et al., 1985c); (2) a development of cellular structures involved in steroidogenesis, mainly smooth endoplasmic reticulum and mitochondria (Durand et al., 1978; Robinson et al., 


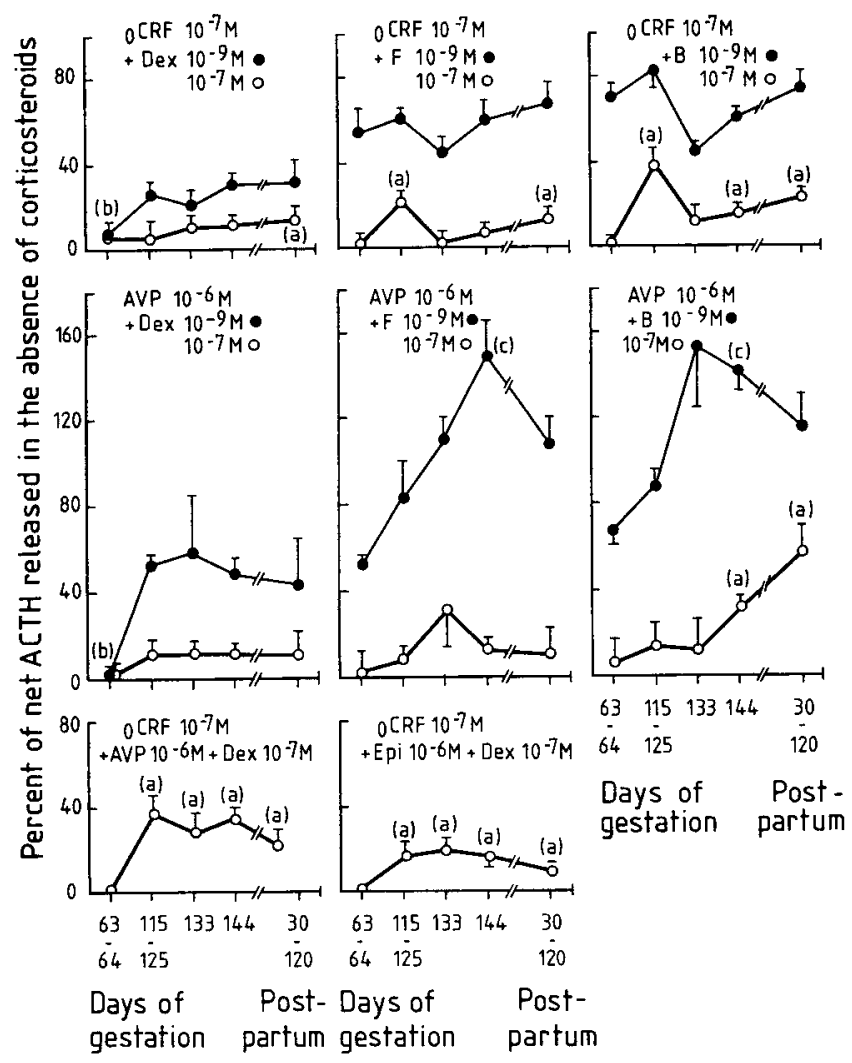

FIG. 2. - Effect of dexamethasone (Dex), cortisol (F), and corticosterone (B) on the net release of $A C T H$ by short term cultured pituitary cells from ovine fetuses and lambs, stimulated by oCRF $1-41$. $A V P, o C R F_{1-41}$ plus $A V P$, and oCRF ${ }_{1-41}$ p/us epinephrine. Results are expressed as a percentage of the net response obtained in the absence of added corticosteroids which was given an arbitrary value of 100 . Results are the mean + SEM for two experiments at each stage. (a), significantly higher than basal output in the presence of $10^{-7} \mathrm{M}$ corticosteroids $(P<0.05$ to $P<0.01)$; (b), not significantly different from basal output in the presence of $10^{-9} \mathrm{M}$ corticosteroids $(P>0.05)$; (c), significantly higher than in the absence of corticosteroids $(\mathrm{P}<0.05)$. From Durand et al., 1986.

$1979)$; this development is associated with an enhancement of some enzymatic activities of the steroidogenic pathway (Anderson et al., 1972; Durand et al., 1982a ; Challis et al., 1986). In addition, it has been shown that ACTH itself can induce the " maturation » of most of these enzymatic steps in vivo (Durand et al., 1981a, c ; 1982a) and in vitro (Durand et al., 1982b ; Cathiard et al., 1985). However nothing is known concerning the development of those steps allowing transmission of the hormonal signal from the plasma membrane receptors to the intracellular structures which express the response of the cell. Likewise the mechanisms involved in the regulation of intracellular cholesterol concentrations in the ovine fetal adrenal cells remain obscure. 
1) Protein kinase activities in ovine adrenal cytosol (Durand et al., 1987c).

In mature adrenocortical cells, the ACTH-induced formation of cAMP is followed by binding of the nucleotide to a protein kinase which, in turn, triggers specific cellular protein phosphorylation, ultimately resulting in biological responses such as steroidogenesis (Saez et al., 1981). In addition to CAMP-dependent protein kinases, cAMP-independent activities have been demonstrated in adult bovine adrenal cortex: a calcium-activated phospholipid-dependent protein kinase (Vilgrain et al., 1984) and two types of casein kinases (Cochet et al., 1980).

In a recent work, we have studied the ontogeny of some protein kinase activities present in the cytosol of ovine adrenal glands during the last month of intrauterine life and at early neonatal stages. Two major peaks corresponding to type I and type II of cAMP-dependent histone kinase activity and 2 major peaks corresponding to type $A$ and type $G$ of cAMP-independent casein kinase activities were observed from 110 days of gestation. The specific activity of each enzyme increased two-fold between 118 days of gestation and 6 days post partum. However, whereas plasma corticosteroid and the in vitro responsiveness of adrenal cells to ACTH were enhanced following infusion of ACTH $_{1-24}$ $(100 \mu \mathrm{g} /$ day) for 5 days to 118-128-day old ovine fetuses, casein kinase $A$ and $\mathrm{G}$, but not histone kinases, were increased by this treatment. Thus, in relation to current concepts of the role of protein kinases in adult adrenal cells, the above results suggest that casein kinase activities are involved in both the cell multiplication and differentiation which occur in the fetal adrenal gland either spontaneously at the end of gestation or after ACTH infusion to the fetus. In addition, the data show that neither type I nor type II cytosolic histone kinase is likely to be rate-limiting in the steroidogenic response of fetal adrenal cells to ACTH.

2) Mechanisms of cholesterol homeostasis in the ovine fetal adrenal gland (Durand et al., 1987a ; Durand et al., 1988).

It seems quite clear that the increasing capability of fetal adrenal cells to produce corticosteroids before birth is mainly related to alterations located early in the steroidogenic pathway which lead to an increased production of pregnenolone (Durand et al., 1982a ; 1984). Such a phenomenon could be due to two processes : (1) increased amounts of cholesterol available for steroidogenesis; (2) enhanced conversion of cholesterol to pregnenolone. Adult steroidogenic cells can obtain cholesterol from two sources : de novo synthesis from C2 units, and plasma lipoproteins (Andersen and Dietschy, 1979; Gwynne and Strauss, 1982). However for ovine fetal adrenal cells the origin of cholesterol is not established. The aim of our studies was three-fold: (1) to compare the stocks of cholesterol present in adrenal cells from ovine fetuses and newborn lambs ; (2) to determine the capacity of these cells to regulate their stocks of cholesterol by de novo synthesis from $\mathrm{C} 2$ units; (3) to assess whether the secretion of corticosteroids by fetal and neonatal adrenal cells was dependent on the presence 
of serum lipoproteins, and if so, the relative importance of very low density lipoproteins (VLDL), low density lipoproteins (LDL) and high density lipoproteins (HDL).

In the first trial, we measured the concentration of free cholesterol and of cholesteryl ester in total homogenates and mitochondrial fractions of adrenal glands from ovine fetuses and newborn lambs (table 2). In total homogenates,

\section{TABLE 2}

Concentrations of free cholesterol and of cholesteryl ester in total homogenate and in mitochondria of adrenal glands from ovine fetuses and newborn lambs.

\begin{tabular}{llccccc}
\hline & \multicolumn{3}{c}{ Fetuses } & \multicolumn{2}{c}{ Newborns } \\
\cline { 3 - 7 } & & \multicolumn{2}{c}{$\begin{array}{c}\text { nmoles/2 } \\
\text { adrenals }\end{array}$} & $\begin{array}{c}\text { nmoles/mg } \\
\text { protein }\end{array}$ & $\begin{array}{c}\text { nmoles/2 } \\
\text { adrenals }\end{array}$ & $\begin{array}{c}\text { nmoles/mg } \\
\text { protein }\end{array}$ \\
\cline { 3 - 7 } Total & Free cholesterol & 2844 & $\pm 262^{\mathrm{a}}$ & $202 \pm 34$ & $7186 \pm 712$ & $199 \pm 10$ \\
homogenate & Cholesteryl ester & 19 & $4^{\mathrm{b}}$ & $1.3 \pm 0.3^{\mathrm{b}}$ & $2176 \pm 588$ & $57 \pm 10$ \\
Mitochondria & Free cholesterol & $184 \pm \pm 47^{\mathrm{b}}$ & $295 \pm \pm 31^{\circ}$ & $1591 \pm 122$ & $663 \pm 54$ \\
& Cholesteryl ester & $3.6 \pm$ & $2.3^{\mathrm{b}}$ & $4.9 \pm 3.1^{\mathrm{b}}$ & $277 \pm 85$ & $109 \pm 18$ \\
\hline
\end{tabular}

Results are the mean \pm SEM for 4 fetuses and 4 newborn lambs

$a: p<0.01$ vs corresponding value in newborns.

$\mathrm{b}: \mathrm{p}<0.001$ vs corresponding value in newborns.

the concentration of free cholesterol was similar in fetal and neonatal adrenal glands. Conversely, for cholesteryl ester, the concentration was 40 -fold lower in fetuses. In mitochondrial fractions, both cholesterol and cholesteryl ester concentrations were lower (2-fold and 22-fold respectively) in fetuses than in newborn animals. This was correlated with a 3-hydroxy-3-methylglutaryl-coenzyme A reductase (HMGCoA-reductase) activity [believed to be the main rate-limiting step in the biosynthesis of cholesterol (Rodwell et al., 1976)] which was 2-fold lower in fetal than in neonatal adrenals. Next, we observed that the secretion of steroids by both fetal and neonatal adrenal cells was lower after several days of culture in serum-free media than that of cells maintained in the presence of $2 \%$ horse serum. Since a "non specific effect" of serum was shown to be very unlikely, these results suggest that de novo cholesterol biosynthesis alone is not able to meet the demand of steroidogenic precursors of these cells. This assumption is strengthened by the enhancement of steroidogenesis which was achieved when appropriate lipoproteins were added to the culture medium. In addition, these latter studies indicated that both an "LDL pathway" and an "HDL pathway " were operating in adrenal celis from fetal as well as newborn sheep. Finally, since the concentration of cholesterol in both LDL and HDL fractions was shown to be equal or even higher than the concentrations required to maximally increase steroidogenesis by adrenal cells from fetuses or newborn lambs, it seems likely that, in vivo, cholesterol availability in plasma is not a 
limiting factor for the adrenal steroidogenesis of these animals. In conclusion, it appears that the low concentration of cholesterol in fetal adrenal cells might be an additional parameter limiting their steroidogenesis. This deficiency can be correlated to a low activity of fetal adrenal HMGCoA-reductase activity. However whether it also conveys a relative deficiency of the LDL-and/or HDL-pathway remains to be determined.

\section{Extra-pituitary regulation of ovine fetal adrenal maturation.}

1) Additional evidence for the occurrence of non-hypophyseal factor(s) inhibiting adrenal function during fetal life (Durand et al., 1985a, 1987b).

Wintour et al. (1975) first, reported that adrenal cells from sheep fetuses on days 50-65 of intrauterine life could respond in vitro to $\mathrm{ACTH}$ with a rather large increase in both cortisol and corticosterone outputs. Hence it appears that throughout the last two-thirds of gestation, the ovine fetal adrenal gland exhibits different levels of steroidogenic responsiveness to ACTH, the lowest occurring between 100 and 130 days of intrauterine life. Few data are available which can explain the high steroidogenic potency of adrenal cells from 55-65-day old ovine fetuses and the reasons for the loss of responsiveness to ACTH of older adrenal cells. In an attempt to better understand these phenomena, we have studied adrenal adenylate cyclase and steroidogenic activities of 62-63-day old ovine fetuses in either freshly isolated cells or in cells cultured for several days in the absence or presence of either $\mathrm{ACTH}_{1-24}$ or of forskolin. $\mathrm{ACTH}_{1-24}$, cholera toxin and forskolin stimulated strongly both CAMP and corticoïd productions by freshly isolated adrenal cells (fig. 3 ). Also, these cells metabolized quickly $\left[{ }^{14} \mathrm{C}\right]$-labeled pregnenolone mainly through the 17-deoxy pathway. When the cells were cultured for 6 days in the absence or presence of $\mathrm{ACTH}_{1-24}$ or forskolin, a small development of the CAMP response to these factors was observed in the course of the experiment. Likewise, the amounts of corticosterone secreted on day 6 by $\mathrm{ACTH}_{1-24}$ or forskolin-treated cells were 2- to 4-fold higher on day 6 than on day 1. However, on day 6 of the experiment, the metabolism of $\left[{ }^{14} \mathrm{C}\right]$ pregnenolone was lower than on day 1 , irrespective of the conditions of culture. Taken together, these results provide evidence that the adrenal adenylate cyclase system of 62-63-day old ovine fetuses is probably not a bottleneck in the steroidogenic response of freshly isolated cells to $\mathrm{ACTH}_{1-24}$ [as opposed to the situation observed in 100-200-day old ovine fetuses (Durand et al., 1981a, b]. They also indicate that neither ACTH nor forskolin, while inducing some development of the responsiveness of the cell adenylate cyclase system to these factors, can maintain the activity of most of the enzymes involved in adrenal metabolization of pregnenolone, but they may increase pregnenolone availability. Finally, since corticotropin-like bioactivity would appear to increase between days 63 and 125 of gestation (see above), i.e. at the time of the progressive loss of responsiveness of fetal adrenal cells to ACTH, these data suggest that some inhibiting factors are also involved in this loss of responsiveness and that they act mainly on the adenylate cyclase system. The extrapituitary origin of these putative inhibiting 

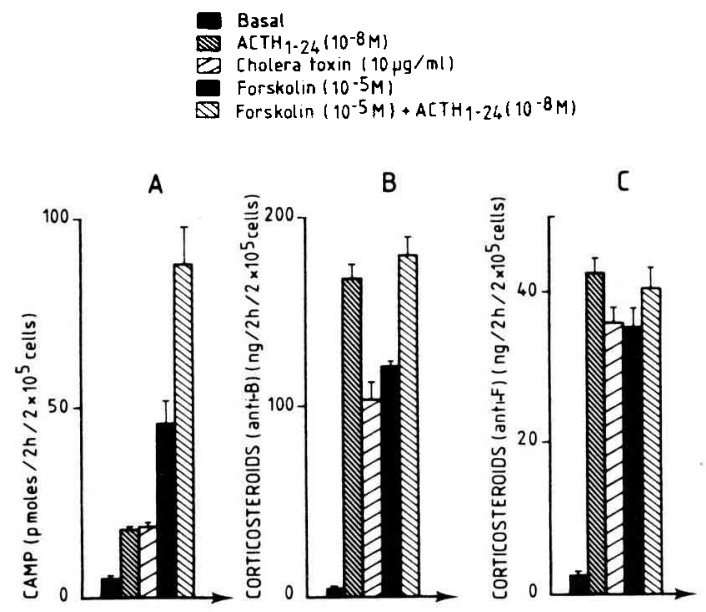

FIG. 3. - Effect of $A C T H_{1-24}\left(10^{-8} \mathrm{M}\right)$, cholera toxin $(10 \mathrm{~g} / \mathrm{ml})$ and forskolin $\left(10^{-5} \mathrm{M}\right)$ alone or in combination with $A C T H_{1-24}$ on $C A M P(A)$, corticosterone (B) and cortisol (C) output by freshly isolated adrenal cells from 62-63 day old ovins fetuses. Each value is the mean \pm SEM for triplicate determinations in 2 different experiments. From Durand et al., $1987 \mathrm{~b}$.

factors, the existence of which was also suggested by our earlier studies (Durand et al., 1982b, 1984), is supported by several lines of evidence: (1) pituitary extracts from 124-day old ovine fetuses induced the same «maturation " of 113-day-old ovine fetal adrenal cells in vitro as did pituitary extracts from 5-day old lambs ; (2) as regards both cAMP and corticosteroid production, we observed a slower development in vitro of the response to $\mathrm{ACTH}_{1-24}$ in cells from hypophysectomized fetuses than in cells from intact fetuses; (3) no adrenal cells at all developed in vivo in the absence of pituitary between 113 and 127 days of gestation, which suggests that putative inhibiting factors were still present after hypophysectomy.

These in vivo/in vitro experiments are in keeping with previous works performed by others in vivo. $\mathrm{ACTH}_{1-24}$ infusion to hypophysectomized fetal sheep can induce parturition, but the corticosteroid concentration achieved generally has a mean value which is below that of intact fetuses (Jones et al., 1978). Likewise, Connors and Liggins (1980) did not observe a greater corticosteroid response to ACTH infusion of ovine fetuses after removal of pituitary gland. The precise origin as well as the nature of such inhibiting factors however remain to be determined.

2) Para and/or autocrine regulation of fetal adrenal maturation (Darbeida et al., 1987 ; Darbeïda and Durand, 1987).

Most tissues in the body appear to possess glucocorticoid receptors (Cake and Litwack, 1975). For a number of these tissues, glucocorticoids are necessary for the full expression of a hormone-induced cellular response. Adult adrenocor- 
tical cells also possess glucocorticoid receptors (Saez et al., 1977 ; Loose et al., 1980). This supports the view that the adrenal gland itself is a target organ for glucocorticoids. Yet the role of these steroids in adrenal function remains a matter of controversy. In the ovine fetus, Liggins (1968) first showed that when metyrapone (an $11 \beta$ hydroxylase inhibitor) was infused together with ACTH, the adrenal hyperplasia which followed $A C T H$ administration did not occur. Also, the same group reported an enhanced adrenal response to ACTH after a fetal infusion of dexamethasone for $48 \mathrm{~h}$ at about 110 days of intrauterine life (Liggins et al., 1977). To get more insight into the mechanism of this action of cortisol on fetal adrenal development, we examined whether exposure to glucocorticoids or to inhibitors of steroid synthesis in vitro could affect the release of cAMP and/or corticosteroids by cultured adrenal cells from 120-138-day old ovine fetuses.
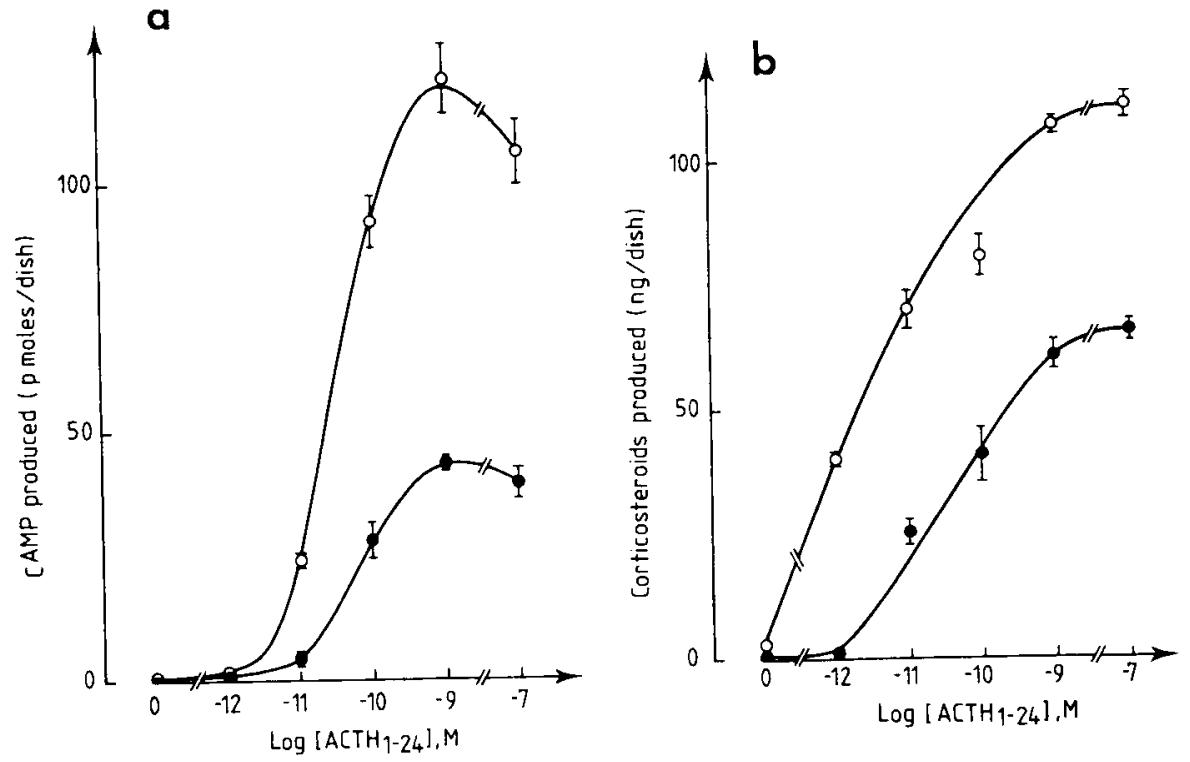

FIG. 4. - Effect of increasing concentrations of ACTH 124 on $C A M P$ (a) and corticosteroid (b) productions by adrenocortical cells from 120 day old ovine fetuses cultured for $48 \mathrm{~h}$ in the absence ( the mean \pm SEM of triplicate determinations for 3 different dishes. From Darbeida et al., 1987.

The CAMP response to $\mathrm{ACTH}_{1-24}$ of cells cultured for $24 \mathrm{~h}$ in the presence of $\mathrm{ACTH}_{1.24}$ was 2-fold higher than that of control cells. However, the response of cells cultured in the presence of $\mathrm{ACTH}_{1.24}$ plus metyrapone or aminoglutethimide [which inhibits cholesterol side-chain cleavage activity (Touitou et al., 1973)] was lower than that of cells cultured in the presence of $\mathrm{ACTH}_{1-24}$ alone. Conversely, cells cultured for $48 \mathrm{~h}$ in the presence of dexamethasone or cortisol 
released more cAMP than control cells when stimulated by $\mathrm{ACTH}_{1-24}$ (fig. 4a), but not in response to forskolin. Similar effects were observed both in the absence and presence of inhibitors of phophodiesterases. Also, corticosteroid production stimulated by $\mathrm{ACTH}_{1-24}$ (fig. 4b), forskolin or dibutyryl cAMP was enhanced by dexamethasone treatment. The maximal effect of dexamethasone was obtained at a concentration close to $10^{-8} \mathrm{M}$. Corticosteroid treatment did not modify the ED50 of ACTH for CAMP output, but decreased the ED50 for corticosterone production 10 -fold $\left(3 \times 10^{-11} \mathrm{M}\right.$ to $\left.3 \times 10^{-112} \mathrm{M}\right)$. Such an enhancing effect of corticosteroids on adrenal function was already observed at 63 days of intrauterine life (table 3 ). Parallel experiments performed with adult adrenal cells revealed that this effect was specific to glucocorticosteroids and offered preliminary evidence that it was mediated through glucocorticoid receptors. We suggest therefore that glucocorticoids are involved in both ACTH-induced and ACTH-independent maturation of the ovine fetal adrenal gland by a direct effect on fetal fasciculata-reticularis cells. The physiological significance of this assumption is strongly supported by the decrease in $\mathrm{ACTH}_{1.24}$-induced cAMP output, found when adrenal cells were cultured in the presence of inhibitors of steroidogenesis, together with the attenuation of $\mathrm{ACTH}$-induced activation of fetal adrenal function in vivo by concurrent metyrapone infusion (Liggins, 1968 ; Lye and Challis, 1984).

\section{TABLE 3}

Effect of a $48 \mathrm{~h}$ treatment with dexamethasone on ACTH 1.24 -induced corticosteroid production by cultured adrenal cells from 63 day old ovine fetuses.

\begin{tabular}{|c|c|c|}
\hline $\begin{array}{l}\text { Treatment with } \\
10-8 \mathrm{M} \text { dexamethasone }\end{array}$ & Stimulation & $\begin{array}{l}\text { Corticosteroids } \\
\text { (ng/dish) }\end{array}$ \\
\hline- & none & $0.9 \pm 0.1$ \\
\hline - & $\begin{array}{l}\text { ACTH } \mathrm{H}_{1} \cdot 24 \\
\left(10^{-11} \mathrm{M}\right)\end{array}$ & $5.5 \pm 0.3$ \\
\hline- & $\begin{array}{l}\text { ACTH }_{1-24} \\
\left(10^{-8} M\right)\end{array}$ & $138 \pm 17$ \\
\hline+ & $\begin{array}{l}\text { ACTH } \\
\left(10^{-11}-24\right. \\
M)\end{array}$ & $35.6 \pm 4.5^{*}$ \\
\hline+ & $\begin{array}{l}\text { ACTH }{ }_{1} 24 \\
\left(10^{-8} \mathrm{M}\right)\end{array}$ & $170 \pm 5^{*}$ \\
\hline
\end{tabular}

$* \mathrm{P}<0.05$ vs corresponding control

\section{Concluding remarks.}

The above results reinforce the view that ACTH-related molecules released by the fetal pituitary are important factors for the regulation of the ovine fetal adrenocortical function. In addition, they offer evidence that not only quantitative but qualitative changes in the pituitary drive to the fetal adrenal has to be taken 
in account to explain the rising corticosteroid plasma levels in prepartum animals. Finally they suggest that extra-pituitary hormones may be operating during fetal life, to reverse at some stages and to accelerate at others the maturation of adrenocortical cells.

Reçu en octobre 1987. Accepté en avril 1988

Acknowledgements. - These studies were supported by grants for I.N.R.A. (A.I.P. 27/443, "Hormones hypophysaires et fonction de reproduction chez les Vertébrés ") and I.N.S.E.R.M. (PRC 82-984).

\section{Résumé. Développement de l'axe hypophyso-surrénalien dans l'espèce ovine.}

Chez le fœtus ovin, les niveaux plasmatiques de corticostéroïdes restent très bas entre 60 et 130 jours de gestation, puis augmentent fortement avant la naissance. L'ACTH semble être le facteur essentiel impliqué dans la régulation du cortex surrénalien fotal dont la sensibilité à cette hormone augmente en fin de gestation. Cependant, les relations entre, I'ACTH immunoreactive et les corticostéroïdes fœetaux sont mal définies. Nous résumons ici les résultats récents obtenus dans notre laboratoire sur la régulation de la sécrétion d'ACTH par les cellules hypophysaires du fœtus ovin et sur les étapes biochimiques impliquées dans l'augmentation de la réponse stéroïdogénique à l'ACTH des cellules surrénaliennes fœtales. Il apparaît que des changement qualitatifs et quantitatifs du contrôle hypophysaire sur la surrénale doivent être pris en considération pour expliquer l'augmentation prépartum des corticostéroïdes plasmatiques. En outre, ces résultats indiquent que d'autres hormones, non hypophysaires, doivent réguler la fonction corticosurrénalienne du fœetus ovin.

\section{References}

ANDERSEN J. M., DIETSCHY J. M., 1979. Absolute rates of cholesterol synthesis in extra hepatic tissues measured with $3 \mathrm{H}$ labelled water and 14C labelled substrats. J. Lipid Res., 20 , 740-702.

ANDERSON A. B. M., PIERREPOINT C. G., GRIFFITHS K., TURNBULL A. C., 1972. Steroid metabolism in the adrenals of fetal sheep in relation to natural and $\mathrm{ACTH}$-induced parturition. J. Reprod. Fertil., 16, 25-37.

ALEXANDER O. P., BRITTON H. G., JAMES V. H. T., NIXON D. A., PARKER R. A., WINTOUR E. M., WRIGHT R. D., 1968. Steroid secretion by the adrenal gland of fetal and neonatal sheep. J. Endocr., 40, 1-13.

BASSETT J. M., THORBURN G. D., 1969. Fetal plasma corticosteroids and the initiation of parturition in sheep. J. Endocr., 44, 285-286.

BRIEU V., DURAND Ph., 1987. Changes in the ratio of bioactive to immunoreactive adrenocorticotropin-like activity released by pituitary cells from ovine fetuses and lambs. Endocrinology, 120, 936-940.

CAKE M. H., LITWACK G. L., 1975. The glucocorticoid receptor, 3, 319-332. In LITWACK G. L., Biochemical actions of hormones, Acad. Press, New York.

CATHIARD A. M., CROZAT A., DURAND Ph., SAEZ J. M., 1985. In vitro spontaneous and ACTH-dependent maturation of the steroidogenic pathway of ovine fetal adrenal cells. Endocrinology, 116, 585-590.

CHALLIS J. R. G., JONES C. T., ROBINSON J. J., THORBURN G. D., 1977 . Development of fetal pituitary adrenal function. J. Steroid Biochem., 8, 471-478. 
CHALLIS J. R. G., LYE S. J., WELSH J., 1986. Ovine fetal adrenal maturation at term and during fetal ACTH administration : evidence that the modulating effect of cortisol may involve cAMP. Can. J. Physiol. Pharmacol., 64, 1085-1090.

COCHET C., JOB D., PIROLlet F., ChAMBAZ E. M., 1980. Adenosine 3', 5' monophosphate-independent protein kinase activities in the bovine adrenal cortex cytosol. Endocrinology, 106, 750-707.

CONNORS M. H., LIGGINS G. C., 1980. Adrenocortical responses to ACTH in the hypophysectomized ovine fetus. J. Dev. Physiol., 2, 183-190.

DARBEÏDA H., DURAND Ph., 1987. Glucocorticoid enhancement of ACTH-induced cAMP production by cultured ovine adreno cortical cells. Endocrinology, 121, 1051-1055.

DARBEİDA H., NAAMAN E., DURAND Ph., 1987. Glucocorticoid induction of the maturation of ovine fetal adrenocortical cells. Biochem. Biophys. Res. Commun., 145, 999-1005.

DURAND Ph., 1979. ACTH-receptor levels in lamb adrenals at late gestation and early neonatal stages. Biol. Reprod., 20, 837-845.

DURAND Ph., 1987. Développement de l'axe hypophyso-surrénalien au cours de la vie fœale: modalités et régulations. Ann. Endocrinol., 48, 301-310.

DURAND Ph., BOSC M., NICOLLE A., 1978. Croissance des surrénales de fœus ovin en fin de gestation : évolution de l'ADN et des protéines membranaires. C. R. Acad. Sci., Paris, Sér. D., 287, 297-300.

DURAND Ph., CATHIARD A. M., DACHEUX F., NAAMAN E., SAEZ J. M., 1986. In vitro stimulation and inhibition of adrenocorticotropin release by pituitary cells from ovine fetuses and lambs. Endocrinologv, 118, 1387-1394.

DURAND Ph., CATHIARD A. M., LOCATELLI A., DAZORD A., SAEZ J. M., 1981a. Spontaneous and $A C T H$-induced maturation of the responsiveness of fetal adrenal cells to in vitro stimulation by $\mathrm{ACTH}_{1-24}$ and choleratoxin. Endocrinology, 109, 2117-2123

DURAND Ph., CATHIARD A. M., LOCATELLI A., SAEZ J. M., 1982a. Modification of the steroidogenic pathway during spontaneous and $A C T H$-induced maturation of ovine fetal adrenal. Endocrinology, 110, 500-505.

DURAND Ph., CATHIARD A. M., LOCATELLI A., SAEZ J. M., 1985a. Effects of fetal hypophysectomy and the in vitro treatment by pituitary extracts on the maturation of cultured ovine fetal adrenal cells. Endocrinology, 116, 578-584

DURAND Ph., CATHIARD A. M., MORERA A. M., DAZORD A., SAEZ J. M., 1981b. Maturation of ACTH-sensitive adenylate cyclase of ovine fetal adrenal during late pregnancy. Endocrinologv, 108, 2114-2119.

DURAND Ph., CATHIARD A. M., NAAMAN E., BRIEU V., SAEZ J. M., 1987a. The influence of plasma lipoproteins on steroidogenesis of cultured ovine fetal and neonatal adrenal cells. J. Steroid Biochem., 26, 425-431.

DURAND Ph., CATHIARD A. M., NAAMAN E., SAEZ J. M., 1987b. Adrenal adenylate cyclase and steroidogenic activities of 63 day old ovine fetuses: in vitro effects of $A_{C T H} H_{1-24}$ and forskolin. Biochimie, 69, 629-638.

DURAND Ph., CATHIARD A. M., NAAMAN E., SAEZ J. M., 1988. De novo synthesis of cholesterol by ovine fetal and neonatal adrenocortical cells. Mol. cell. Endocrinol., 57, 215-223.

DURAND Ph., CATHIARD A. M., SAEZ J. M., 1982b. In vitro maturation of ovine fetal adrenal adenylate cyclase: ACTH dependent and independent development of the response to ACTH. Biochem. Biophys. Res. Commun., 106, 8-15.

DURAND Ph., CATHIARD A. M., SAEZ J. M., 1984. In vitro maturation of steroidogenic capacity of ovine fetal adrenal cells. Endocrinology, 114, 1128-1134.

DURAND Ph., CATHIARD A. M., SAEZ J. M., 1985b. Maturation of the ovine fetal adrenal gland: in vivo and in vitro studies, 31 -52. In JAFFE R. B., DELL-ACOUA S., The endocrine physiology of pregnancy and the peripartal period. Raven Press, New York.

DURAND Ph., CATHIARD A. M., SAEZ J. M., 1985c. Involvement of the regulatory protein (Ns) in the maturation of ACTH-sensitive adenylate of ovine fetal adrenal during late gestation. Mol. cell. Endocrinol., 39, 145-150.

DURAND Ph., LOCATELLI A., CATHIARD A. M., DAZARD A., SAEZ J. M., 1981 c. ACTH induction of the maturation of ACTH sensitive adenylate cyclase system in the ovine fetal adrenal. $J$. Steroid Biochem., 15, 445-448. 
DURAND Ph., VILGRAIN I., CHAMBAZ E. M., SAEZ J. M., 1987c. Changes in protein kinase activities in lambs adrenals at late gestation and early postnatal stages. Mol. cell. Endocrinol., 53, 195-202.

GWYNNE J. T., STRAUSS J. F., 1982. The role of lipoproteins in steroidogenesis and cholesterol metabolism in steroidogenic glands. Endocr. Rev., 3, 299-329.

HENNESSY D. P., GOGHLAN J. P., HARDY K. J., WINTOUR E. M., 1982. Development of the pituitary-adrenal axis in chronically cannulated ovine fetuses. J. Dev. Physiol., 4, 339-352.

JONES C. T., BODDY K., ROBINSON J. S., 1977. Changes in the concentration of ACTH and corticosteroids in the plasma of fetal sheep in the late half of pregnancy and during labour. J. Endocrinol., 72, 293-300

JONES C. T., KENDALL J. Z., RITCHIE J. W. K., ROBINSON J. S., THORBURN G. D., 1978. Adrenocorticotrophin and corticosteroid change during dexamethasone infusion to intact and synacthen infusion to hypophysectomized fetuses. Acta endocrinol., 87, 203-211.

JONES C. T., ROEBUCK M. M., 1980. ACTH peptides and the development of the fetal adrenal. $J$. Steroid Biochem., 12, 77-82.

KELLER-WOOD M. E., DALLMAN M. F., 1984. Corticosteroid inhibition and ACTH secretion. Endocr. Rev., 5, 1-24.

LIGGINS G. C., 1968. Premature parturition after infusion of corticotrophin or cortisol to fetal lambs. J. Endocr., 42, 323-329.

LIGGINS G. C., 1976. Adrenocortical-related maturational events in the fetus. Am. J. Obstet. Gynecol., 126, $931-941$.

LIGGINS G. C., FAIRCLOUGH R. J., GRIWES S. A., FORSSER C. S., KNOX B. S., $1977 . \quad$ Parturition in sheep, 47, 5-30. In KNIGHT J., O'CONNOR M., The fetus and birth, Ciba Foundation Symposium, Elsevier, Amsterdam.

LOOSE D. S., DO Y. S., CHEN T. L., FELDMAN D., 1980. Demonstration of glucocorticoid receptors in the adrenal cortex : evidence for a direct dexamethasone suppressive effect on the rat adrenal gland. Endocrinology, 107, 137-146.

LYE S. J., CHALLIS J. R. G., 1984. In vivo ACTH ${ }_{1-24}$ induced accumulation of cAMP by ovine fetal adrenal cells in inhibited by concomitant infusion of metopyrone. Endocrinology, 115. 1584-1587.

MAGYAR D. M., FRIDSHALL E., ELSNER C. W., GLATZ T., ELLIOT J., KLEIN A. H., LOWE K. L., BUSTER J.E., NATHANIELSZ P.W., 1980. Time trend analysis of plasma cortisol concentrations in fetal sheep in relation to parturition. Endocrinology, 107, 155-159.

NATHANIELSZ P. W., 1978. Endocrine mechanisms of parturition. Ann. Rev. Physiol., 40, 411-445.

NATHANIELSZ P. W., COMLINE R. S., SILVER M., PAISEY R. D., 1972. Cortisol metabolism in the fetal and neonatal sheep. J. Reprod. Fertil., Suppl. 16, 39-59.

NORMAN L. J., LYE S. J., WLODEK M. E., CHALLIS J. R. G., $1985 . \quad$ Changes in pituitary response to synthetic ovine corticotropin-releasing factor in fetal sheep. Can. J. Physiol. Pharmacol., 63, 1398-1403.

REES L. H., JACK P. M. B., THOMAS A. L., NATHANIELSZ P. W., 1975. Role of fetal ACTH during parturition in sheep. Nature, 253, 274-275.

ROBINSON P. M., ROWE E. J., WINTOUR E. N., 1979. The histogenesis of the adrenal cortex in the fetal sheep. Acta endocrinol., 91, 134-149.

RODWELL V. W., NORDSTROM J. L., MITSCHELEN J. J., 1976. Regulation of HMGCOA reductase. Adv. Lipid Res., 14, 1-74.

ROEBUCK M. M., JONES C. T., HOLLAND D., SILMAN R., 1980. In vitro effects of high molecular weight forms of $\mathrm{ACTH}$ on the fetal sheep adrenal. Nature, 284, 616-618.

SAEZ J. M., MORERA A. M., DAZORD A., 1981. Mediators of the effects of ACTH on adrenal cells. Adv. Cyclic Nucleotide Res., 14, 563-579.

SAEZ J. M., MORERA A. M., GALLET D., 1977. Opposite effects of ACTH and glucocorticoids on adrenal DNA synthesis in vivo. Endocrinology, 100, 1268-1275.

SILMAN R. E., HOLLAND D., CHARD T., LOWRY P. J., HOPE J., REES L. H., THOMAS A., NATHANIELSZ P. W., 1979. Adreno corticotropin-related peptides in adult and foetal sheep pituitary glands. J. Endocrinol., 81, 19-34.

THORBURN G. D., CHALLIS J. R. G., 1979. Endocrine control of parturition.Physiol. Rev., 59, 863-918. 
TOUITOU Y., LEGRAND G. C., DESGREZ P., 1973. Adrenocortical steroidogenesis and aminoglutethimide: I. Biochemical studies. Biomedicine, 18, 185-191.

VILGRAIN I., COCHET C., CHAMBAZ E. M., 1984. Hormonal regulation of a $\mathrm{Ca}^{++}$activated phospholipid dependent protein kinase in bovine adrenal cortex. J. biol. Chem., 259, 3403-3406.

WEBB P. D., 1980. Development of the adrenal cortex in the fetal sheep : an ultra structural study. J. dev. Physiol., 2, $161-181$.

WINTOUR E. M., BROWN E. H., DENTON D. A., HARDY D. J., McDOUGALL J. G., ODDIE C. J., WHIPP G. T., 1975. The ontogeny and regulation of corticosteroid secretion by the ovine fetal adrenal. Acta endocrinol., 79, 301-316.

WINTOUR E. M., COGHLAN J. P., HARDY K. L., HENNESSY D. P., LINGWOOD B. E., SCOGGINS B. A., 1980. Adrenal corticosteroids and immunoreactive ACTH in chronically cannulated ovine fetuses with bilateral adrenalectomy. Acta endocrinol., 95, 546-552.

YASUDA N., GREER M. A., AIZAWA T., 1982. Corticotropin-releasing factor. Endocr. Rev., 3, 123-140.

YATES F. E., MARAN J. W., 1974. Stimulation and inhibition of ACTH release, 367-404. In KNOBIL E., SAWYER W. H. Handbook of physiology, sect. 7, vol. 4. Am. Physiol. Soc., Washington DC. 